International Research Journal of Management, IT \& Social Sciences
Available online at https://sloap.org/journals/index.php/irjmis/
Vol. 7 No. 1, January 2020, pages: 145-155
ISSN: 2395-7492
https://doi.org/10.21744/irjmis.v7n1.833

\title{
Effect of Capital Structure and Sales Growth on Firm Value with Profitability as Mediation
}

\author{
I Gusti Agung Prabandari Tri Putri ${ }^{\text {a }}$ \\ Henny Rahyuda ${ }^{\text {b }}$
}

\section{Article history:}

Submitted: 18 November 2019

Revised: 27 December 2019

Accepted: 11 January 2020

\section{Keywords:}

capital structure;

firm value;

mediation;

profitability;

sales growth;

\begin{abstract}
This study aims to examine and analyze the effect of capital structure with the Debt to Equity Ratio proxy, sales growth with Sales Growth proxy and profitability with Return on Asset proxy on firm value with direct and indirect Price Book Value proxy using Return on Asset as a variable intervening. This study uses secondary data sourced from annual reports of 51 Consumer Good industrial companies listed on the Indonesia Stock Exchange for the period 2013-2018 as population. The sample selection is made by a purposive sampling technique that is the existence of certain criteria which are used as the basis for the selection of research samples. The results of the study are DER significant negative effect on ROA, SG significantly positive effect on ROA. DER does not affect PBV. SG has a significant positive effect on PBV. ROA can act as a mediator of the influence of DER, SG, and DPR on PBV.
\end{abstract}

International research journal of management, IT and social sciences (C) 2020. This is an open access article under the CC BY-NC-ND license (https://creativecommons.org/licenses/by-nc-nd/4.0/).

Corresponding author:

I Gusti Agung Prabandari Tri Putri,

Faculty of Economics and Business, Udayana University, Denpasar, Indonesia.

Email address: igaptp95@gmail.com

${ }^{a}$ Udayana University, Denpasar, Indonesia

${ }^{\mathrm{b}}$ Udayana University, Denpasar, Indonesia 


\section{Introduction}

The purpose of the company besides getting profit is maximizing the firm value based on the Theory of The Firm (Jensen \& Meckling, 1976). Managers as decision-makers at least must have more information about the company compared to outside parties. Positive information that shows the company's performance must be shared with investors based on Signal Theory. The goal is that the company information can encourage the creation of firm value because it increases investor confidence in the company. Decisions made by financial managers in creating firm value must be right to get maximum performance. A company that performs well and has good corporate value has another goal which is to provide prosperity for shareholders. The prosperity of shareholders is said to be the ultimate goal of financial managers achieved by maximizing the present value of the current benefits expected to be obtained in the future.

Firm value is the investor's perception of the company's success in managing company resources in year $t$, which can be seen from the stock price during year $t+1$. The level of prosperity of shareholders can be seen from the value of the stock price. The higher the stock price, the more prosperous the shareholders will be because the company has good performance and has prospects for the future. The impact is that many investors who invest in companies can drive high demand and stock prices so that it reflects an increase in the firm value.

Corporate funding decisions can be seen in terms of the company's capital structure. Capital structure is the allocation of company equity and the use of debt to carry out the company's operational activities. The formation of capital structure has an important role in the activities of the company because it can be used as a basis for determining profits. The composition of the capital structure can be a signal for investors in assessing the condition of the company.

Rasyid (2015), based on the results of his research, found that capital structure does not affect firm value. The composition of debt in the company's capital structure will not affect investors' decisions in investing, as long as the company has prospects in the future. This means that no matter how much they use of corporate debt will not affect stock prices and firm value.

The use of debt at a certain value will be beneficial because it can save corporate taxes (Gumanti, 2017). This savings is due to companies that use debt will pay less interest. It is feared that the high use of debt will reduce the firm value. The lower the debt used can increase the firm value. Investors consider low debt that the company has a low bankruptcy risk. Rahman et al. (2019), found the results of the capital structure harmed firm value.

Generally, the manager is part of the company who knows the company information in detail compared to investors. Important company information is needed to assist investors in deciding on investments. The signal theory states that information related to company conditions is needed by investors to make investment decisions and improve their well-being so that it impacts on the company's value. Signal theory shows that capital structure has a positive effect on firm value (Hoque et al., 2014). The use of debt by companies for investment can be a signal for investors if the company has prospects in the future. The maximizing value will fundamentally increase stock prices. Handriani \& Robiyanto (2018), found the results of the capital structure had a positive effect on firm value.

The company that has determined the source of its funding is the next company to plan product sales targets. Product sales are a sustainable activity for the company. The company will establish certain sales strategies to increase sales. Reducing costs can help companies sell products at affordable prices and can help increase sales. Evaluation of sales is important to do. The aim is to create sales growth. The existence of sales growth means, the higher the company's revenue and can affect the firm value, according to the results of research Febriyanto (2018).

Achievement of the management of company resources can be seen from the company's profitability. Profit is the company's main goal that can be used as a benchmark by investors in making investment decisions. Companies that show positive performance become investment opportunities by investors because investors believe in the coming period, the company will get a higher profit. The increase in corporate profits will have an impact on the firm value; this is due to the high confidence of investors to invest, thereby increasing demand and stock prices. This condition is following the results of research Sucuahi \& Jay (2016), found that profitability has a positive effect on firm value.

\section{Literature Review and Hypothesis Development}

Signal theory by Ross (Gumanti, 2017) states the use of debt by companies can show good company performance. A high DER indicates that the company feels optimistic about the profitability that will increase in the next period. The company is considered good by creditors because, to get high debt, the company must show high profits. Seeing growing profits means the company can pay obligations in high nominal terms. The higher the company's debt, the higher the profit the company will get from debt. Nirajini \& Priya (2013); Putra \& Sedana (2019); Safeena \& Hassan 
(2014); Idode et al. (2014); in his research, found the results of capital structure have a positive effect on profitability. The use of large amounts of debt can be tolerated by the company, as long as the benefits of the debt are considered beneficial.

The research hypothesis is as follows:

H1: Capital structure has a positive effect on profitability

The higher sales growth signifies that the company is performing well, thus encouraging company profits to increase. Missy et al. (2016), as well as Odalo et al. (2016), in his research, showed that sales growth has a positive effect on profitability. The results showed a positive direction indicating the higher sales growth would increase company profitability. The company has a determination to market its products to achieve company growth so that it has a positive impact on the company's profitability.

The research hypothesis is as follows:

H2: Sales growth has a positive effect on profitability

Hoque et al. (2014) and Handriani \& Robiyanto (2018), found the results of the capital structure had a positive and significant effect on firm value. A positive effect is shown from the success of the company in utilizing debt in business expansion and getting a positive response from investors. Investors like companies that continue to grow and increase stock demand, thereby increasing share prices. An increase in stock prices indicates the firm value is increasing.

The research hypothesis is as follows:

H3: Capital structure has a positive effect on firm value

Company growth is a benchmark that shows the movement of company activities from the initial investment to a certain period in business improvement. Sales growth means the company has effectively and efficiently sold its products because it has been able to provide a return on investments made. The higher sales growth has an impact on investors' assessment of the company so that it can increase the firm value. The reason for the increase in the firm value is due to the high demand for shares which drives up stock prices. Investors generally like companies that continue to show growth, especially sales. Sales growth means more and more people or consumers who believe in the company's products. Kodongo et al. (2015) and Febriyanto (2018), in their research, found the results of sales growth had a positive effect on firm value. Positive results indicate that sales growth shows the company has good growth prospects, thus providing greater profits. This condition gives a positive perception to investors so that it has an impact on increasing the firm value.

The research hypothesis is as follows:

H4: Sales growth has a positive effect on firm value

Profitability is a ratio that describes the performance of management in managing company resources (Rahayu \& Bida, 2018). Increase in profits will increase the firm value, when the company has optimized the use of assets, increase sales of company products and increase cost-efficiency. The higher the profitability ratio means, the better the productivity of assets in generating profits. The high profitability will show the prospect of a good quality company so that it will be responded positively by the market. Investors will receive a positive signal for reporting information related to the company's good financial performance. Good performance is seen from profit because it shows a return on the investment made by the company. Investors believe if the coming period becomes easy for companies to increase profits. The form of investor participation is by buying shares, which triggers an increase in share prices and has an impact on increasing the firm value. Sucuahi \& Jay (2016) and Handayani et al. (2018), in line with the description above, namely, profitability has a positive effect on firm value.

The research hypothesis is as follows:

H5: Profitability has a positive effect on firm value

The composition of good debt usage is lower than company equity. Low debt indicates that the company has a low risk. Investors will decide to buy shares in companies that can provide good business prospects and have a low risk, especially bankruptcy. Low debt can affect profits because companies don't have to use high amounts of profits to pay interest on loans. Low business risk and offset by high profitability will drive the high demand for the company's shares so that it will increase share prices. High stock prices indicate the firm value increases. Rahman (2012), in his research, found results if profitability mediated the effect of capital structure on firm value.

Putri, I. G. A. P. T., \& Rahyuda, H. (2020). Effect of capital structure and sales growth on firm value with profitability as mediation. International Research Journal of Management, IT and Social Sciences, 7(1), 145-155. https://doi.org/10.21744/irjmis.v7n1.833 
The research hypothesis is as follows:

H6: Profitability acts as a mediating effect of capital structure on firm value

Sales growth can occur when the company's products have been accepted and are attached to the needs of consumers. High demand from the market will have a positive impact on companies, especially in receiving profits. This means that sales growth will produce the maximum profit for the company and increase profitability. High profits make it easy for companies to invest by adding production facilities. The higher the production, the more market demand can be met and again increase profits. This positive information will certainly be responded well by investors by increasing the company's share ownership. Profitability has a positive effect on the effect of sales growth on firm value according to the results of the research of Burhanuddin et al. (2019).

The research hypothesis is as follows:

H7: Profitability acts as a mediating effect of sales growth on firm value.

\section{Materials and Methods}

This study uses profitability as a mediating variable with a Return on Asset (ROA) proxy and a firm value with a Price Book Value (PBV) proxy as an endogenous variable. The exogenous variables chosen are the ratio of capital structure to the Debt to Equity Ratio (DER) proxy, and the ratio of sales growth. The research data used are secondary, meaning that the data obtained from the company's financial statements, documents related to the research company and other supporting data obtained by researchers indirectly but through intermediary media. Secondary data referred to in this study include the annual financial report (annual report) of the Consumer Good industrial companies listed on the Indonesia Stock Exchange for the period 2013-2018. The data was obtained from annual financial reports published from the websites of each company. Research analysis techniques using path analysis with the help of SPSS 25 statistical analysis tools for hypothesis testing. Furthermore, the results of the hypothesis analysis will be interpreted, and conclusions will be drawn at the end of the stage and suggestions.

\section{Results and Discussions}

Testing data in this study uses path analysis (path analysis) with the help of SPSS 25 . This path analysis aims to examine the pattern of relationships that reveal the relationship between variables, both direct and indirect influences. The regression model will be divided into substructure one and substructure two. Table 1 below will present a summary of the results of testing the Debt to Equity Ratio (X1), Sales Growth (X2), Return on Asset (Y1) and Price Book Value (Y2) regression models of research both direct influence, indirect effect, total effect and results in Sobel test calculations. The results of this path analysis can be used to create equations of substructure one and substructure two and calculate the values of e1 and e2.

Table 1

Summary of Path analysis test results

\begin{tabular}{|c|c|c|c|c|c|c|c|}
\hline No & Variable & $\begin{array}{l}\text { Direct } \\
\text { Effect }\end{array}$ & $\begin{array}{l}\text { Indirect } \\
\text { Effect }\end{array}$ & Total Effect & $\begin{array}{l}\text { Sobel } \\
\text { Test }\end{array}$ & Sig & Description \\
\hline 1 & $\mathrm{X} 1 \rightarrow \mathrm{Y} 1$ & $-0,366$ & & & & 0,000 & H1 rejected \\
\hline 2 & $\mathrm{X} 2 \rightarrow \mathrm{Y} 1$ & 0,129 & & & & 0,048 & $\mathrm{H} 2$ accepted \\
\hline 3 & $\mathrm{X} 1 \rightarrow \mathrm{Y} 2$ & $-0,010$ & & & & 0,896 & H3rejected \\
\hline 4 & $\mathrm{X} 2 \rightarrow \mathrm{Y} 2$ & 0,230 & & & & 0,001 & H4 accepted \\
\hline 5 & $\mathrm{Y} 1 \rightarrow \mathrm{Y} 2$ & 0,321 & & & & 0,000 & H5 accepted \\
\hline 6 & $\mathrm{X} 1 \rightarrow \mathrm{Y} 1 \rightarrow \mathrm{Y} 2$ & & $\begin{array}{l}-0,366 \times 0,321 \\
=-0,117\end{array}$ & $\begin{array}{l}-0,010+(-0,117) \\
=-0,127\end{array}$ & 2,40 & & H6 accepted \\
\hline 7 & $\mathrm{X} 2 \rightarrow \mathrm{Y} 1 \rightarrow \mathrm{Y} 2$ & & $\begin{array}{l}0,129 \times 0,321 \\
=0,041\end{array}$ & $\begin{array}{l}0,230+0,041 \\
=0,271\end{array}$ & 2,05 & & H7 accepted \\
\hline & \multicolumn{2}{|c|}{$R^{2}$ substructure $\mathrm{I}=0,157$} & & & & & \\
\hline
\end{tabular}


Based on the results of the path analysis test, substructure one and substructure two are made equations, and the values of $\mathrm{e} 1$ and $\mathrm{e} 2$ are calculated, as follows:

Structure I:

$$
\begin{gathered}
\mathrm{Y}_{1}=\beta_{1} \mathrm{X}_{1}+\beta_{2} \mathrm{X}_{2}++\mathrm{e}_{1} \\
\mathrm{Y}_{1}=-0,093 \mathrm{X}_{1}+0,082 \mathrm{X}_{2}+e_{1} \\
e_{1}\left(\text { error }_{1}\right) \quad \\
=\sqrt{1-\mathrm{R}^{2}} \\
=\sqrt{1-0,157} \\
=0,918
\end{gathered}
$$

Structure II

$$
\begin{aligned}
& \mathrm{Y}_{2}=\beta_{3} \mathrm{X}_{1}+\beta_{4} \mathrm{X}_{2}+\beta_{5} \mathrm{Y}_{1}+\mathrm{e}_{2} \\
& \begin{aligned}
& \mathrm{Y}_{2}=0,001 \mathrm{X}_{1}+0,034 \mathrm{X}_{2}+0,075 \mathrm{Y}_{1}+e_{2} \\
& e_{2}(\text { error2) }=\sqrt{1-\mathrm{R}^{2}} \\
&=\sqrt{1-0,181} \\
&=0,904
\end{aligned}
\end{aligned}
$$

Model Validity Test

The model validity test or the model accuracy test aims to determine the magnitude of the influence of exogenous variables on endogenous variables. Valid or not depends on the underlying assumptions. Indicators of model validity in the path analysis used in this study are the total determination coefficients as follows:

$$
\begin{aligned}
\mathrm{R}^{2} \mathrm{~m} & =1-(\mathrm{e} 1) 2(\mathrm{e} 2) 2 \\
& =1-(0.918) 2(0.904) 2 \\
& =0.319
\end{aligned}
$$

A total determination value of 0.319 means that 31.9 percent of the variation in PBV (Y2) is influenced by ROA (Y1), DER (X1), and SG (X2) while the rest is explained by other factors not included in the study.

\section{Hypothesis Test 1}

The results of testing the effect of capital structure variables (X1) on profitability (Y1) found the results of a significance value of $0,000<0.05$ can be seen in Table 1 . Significance value that is less than the real level of 0.05 indicates if X1 has a significant effect on Y1. The beta value of the capital structure coefficient based on the results of data processing is -0.386 and the $\mathrm{t}$-value is -5.195 , thus $\mathrm{H} 1$ is rejected. The results of this test mean that the capital structure (X1) has a negative and significant effect on profitability (Y1).

\section{Hypothesis Test 2}

The results of testing the effect of sales growth variables (X2) on profitability (Y1) showed a significance value of $0.048<0.05$ with a beta coefficient of 0.129 seen in Table 1 and a tcount of 1.839 . Significance value that is less than the real level of 0.05 indicates that $\mathrm{X} 2$ has a significant effect on $\mathrm{Y} 1$. The results of this test mean that sales growth (X2) has a positive and significant effect on profitability (Y1), so H2 is accepted.

Hypothesis Test 3

The results of testing the effect of capital structure variables (X1) on the Firm Value (Y2) in Table 1 show a significance value of $0.896>0.05$ with a coefficient value of beta -0.010 and value of tcount is -0.131 . Significance value that is greater than the real level of 0.05 means that there is no significant effect between X1 to Y2. This result means that the capital structure (X1) has a negative and not significant effect on firm value (Y2), so H3 is rejected.

\section{Hypothesis Test 4}

The results of testing the effect of sales growth variables (X2) on firm value (Y2) in Table 1 show a significance value of $0.001<0.05$ with a beta coefficient of 0.230 and a tcount of 3.272 . Significance value that is less than the real level of 0.05 means that there is a significant influence of X2 on Y2. The results of this test mean that sales growth (X2) has a positive and significant effect on firm value (Y2) so that $\mathrm{H} 4$ is accepted.

Putri, I. G. A. P. T., \& Rahyuda, H. (2020). Effect of capital structure and sales growth on firm value with profitability as mediation. International Research Journal of Management, IT and Social Sciences, 7(1), 145-155. https://doi.org/10.21744/irjmis.v7n1.833 
Hypothesis Test 5

The results of testing the effect of the profitability variable (Y1) on the Firm Value (Y2) in Table 1 show a significance value of $0,000<0.05$ with a beta coefficient of 0.321 and a calculated value of 4.244 . The significance value is less than the real level of 0.05 , meaning that there is a significant influence of Y1 on Y2. The results of this test mean that profitability (Y1) has a positive and significant effect on firm value (Y2) so that $\mathrm{H} 5$ is accepted.

\section{Hypothesis Test 6}

Hypothesis 6 testing related to the role of profitability (Y1) as a mediating variable the effect of capital structure (X1) on firm value (Y2), is carried out with the sobel test as follows:

$\mathrm{Sa}_{1} \mathrm{~b}$

$$
\begin{aligned}
& \mathrm{Sa}_{1} \mathrm{~b}=\sqrt{\mathrm{b}^{2} \mathrm{sa}_{1}{ }^{2}+\mathrm{a}_{1}{ }^{2} \mathrm{sb}^{2}+\mathrm{sa}_{1}{ }^{2} \mathrm{sb}^{2}} \\
& \mathrm{Sa}_{1} \mathrm{~b}=\sqrt{(0,075)^{2}(0,035)^{2}+(0,082)^{2}(0,018)^{2}+(0,035)^{2}(0,018)^{2}} \\
& \mathrm{Sa}_{1} \mathrm{~b}=0,0029
\end{aligned}
$$

$a_{1} b$

$$
\begin{aligned}
& a_{1} b=a_{1} \times b \\
& a_{1} b=-0,093 \times 0,075 \\
& a_{1} b=-0,0069
\end{aligned}
$$

Perhitungan nilai $\mathrm{t}_{1}$

$$
\mathrm{t}_{1}=\frac{\mathrm{a}_{1} \mathrm{~b}}{\mathrm{sa} \mathrm{I}_{1} \mathrm{~b}}=\frac{-0,0069}{0,0029}=2,40
$$

Information:

$b^{2}=$ value of $\mathrm{Y} 1$ substructure 2

$a^{1}=$ value $\beta$ X1 substructure 1

$\mathrm{Sa}_{1}=$ default value of error $\mathrm{X} 1$ substructure 1

$\mathrm{Sb}_{2}=$ default value of error $\mathrm{Y} 1$ substructure 2

The value of $t 1$ is 2.40 which is then compared with the value of the table, where $2.40>1.96$ means that profitability is able to mediate the effect of capital structure on firm value. These results prove if $\mathrm{H6}$ is accepted.

\section{Hypothesis Test 7}

Hypothesis 7 testing related to the role of profitability (Y1) as a mediator of the effect of sales growth (X2) on firm value (Y2), is carried out with the Sobel test as follows:

$\mathrm{Sa}_{1} \mathrm{~b}$

$$
\begin{aligned}
& \mathrm{Sa}_{1} \mathrm{~b}=\sqrt{\mathrm{b}^{2} \mathrm{sa}_{1}{ }^{2}+\mathrm{a}_{1}{ }^{2} \mathrm{sb}^{2}+\mathrm{sa}_{1}{ }^{2} \mathrm{sb}^{2}} \\
& \mathrm{Sa}_{1} \mathrm{~b}=\sqrt{(0,075)^{2}(0,010)^{2}+(-0,093)^{2}(0,018)^{2}+(0,010)^{2}(0,018)^{2}} \\
& \mathrm{Sa}_{1} \mathrm{~b}=0,0030
\end{aligned}
$$

$a_{1} b$

$$
\begin{aligned}
& a_{1} b=a_{1} \times b \\
& a_{1} b=0,082 \times 0,075 \\
& a_{1} b=0,00615 \\
& t_{2}=\frac{a_{1} b}{s a_{1} b}=\frac{0,00615}{0,0030}=2,05
\end{aligned}
$$

Information:

$\mathrm{b}^{2}=$ value of $\mathrm{Y} 1$ substructure 2

$\mathrm{a}^{1}=$ value $\beta \mathrm{X} 1$ substructure 1

$\mathrm{Sa}_{1}=$ default value of error $\mathrm{X} 1$ substructure 1

$\mathrm{Sb}_{2}=$ default value of error Y1 substructure 2

The $\mathrm{t} 2$ value is 2.05 , then this value is compared with the table value, where 2.05>1.96 means that profitability is able to mediate the effect of sales growth on firm value. These results indicate if $\mathrm{H} 7$ is accepted. 


\section{The Effect of Capital Structure on Profitability}

The results of hypothesis testing indicate that capital structure has a negative and significant effect on profitability. The negative effect indicates that the higher the capital structure, the lower profitability, so the results show that $\mathrm{H} 1$ is rejected.

Companies need large amounts of funds to cover the costs of their activities so that equity will be combined with debt. High and low debt will have an impact on earnings because the debt used by companies is obliged to pay interest on the loan. The higher the debt means the higher the loan interest to be paid. The high-interest payments will affect the profit decline. The negative impact means the use of high debt does not benefit the company, because the company has not been able to use debt to increase profitability. The results of this study support the empirical study by Tailab (2014); Khan \& Imran (2015) and Rahman et al. (2019).

\section{The effect of sales growth on profitability}

Growth is generally expected by internal and external parties, especially investors because it will have a positive impact on both parties. One of them is sales growth which has an important role in projecting future profits. The results of hypothesis testing found that sales growth had a positive and significant effect on profitability, so $\mathrm{H} 2$ was accepted. Positive direction means sales growth will have an impact on increasing company profits. Sales must be able to cover costs to be able to increase profits so the company can determine strategies in anticipating the increase or decrease in sales in the coming period (Missy et al., 2016). Profit can be maximized by adding production facilities. The addition of production facilities can increase the number of products offered so that sales growth opportunities can be met. The results of this study support the empirical study by Missy et al. (2016) and Odalo et al. (2016).

\section{The effect of capital structure on firm value}

The capital structure shows the composition of the use of equity and debt in the company's operations. The results of hypothesis testing found that capital structure has a negative and not significant effect on firm value, so $\mathrm{H} 3$ is rejected. Negative influence means that the higher the use of debt as forming capital structure will reduce the Firm Value. High debt can provide high risk for companies because the amount of debt will be proportional to the obligations that must be paid. The problem that arises is the inability of companies to pay interest on loans that encourage the risk of bankruptcy. The increase in debt by companies will be responded negatively by investors so that it can reduce the Firm Value. The negative results of testing the effect of capital structure on firm value support the empirical study found by Paminto et al. (2016).

Overall, the results of capital structure testing on the firm value obtained by this study are negative and insignificant, meaning that capital structure has no effect on firm value. These results are in line with the empiricism obtained by Saputra et al. (2019); Rasyid (2015); and Sudiani (2018). An increase or decrease in the use of debt in the capital structure does not cause high or low Firm Value, because investors see investment risks from various sides of the financial statements not only on the capital structure.

\section{The effect of sales growth on firm value}

Sales growth is an ongoing process of the company. Growth means the company is performing well, creating a positive image for the company. The test results found that sales growth had a positive and significant effect on firm value, so H4 was accepted. This means that higher sales growth will have an impact on increasing the Firm Value.

Sales growth information is used by many parties such as company owners, investors, creditors and others to see the company's prospects. The importance of past sales data can help companies optimize their resources to develop Firm Value. Sales growth is a positive indicator to assess the Firm Value because sales growth reflects the condition of the company better than before. The higher investor confidence in sales growth drives stock purchases and the high demand for shares results in an increase in stock prices and Firm Value. The results of this study are in line with Kodongo et al. (2015) and Febriyanto (2018), who found sales growth to have a positive and significant effect on firm value.

Putri, I. G. A. P. T., \& Rahyuda, H. (2020). Effect of capital structure and sales growth on firm value with profitability as mediation. International Research Journal of Management, IT and Social Sciences, 7(1), 145-155. https://doi.org/10.21744/irjmis.v7n1.833 


\section{The Effect of Profitability on Firm Value}

Profitability is explained as the ratio of profits derived by the company from the benefits of its investment. The test results show that profitability has a positive and significant effect on firm value so that H5 is accepted. Positive direction means the higher profitability, the impact on increasing the Firm Value.

Positive information related to company performance bodes well for investors. An increase in profitability shows if the company is performing well because it has received a return on investment. The high profitability of the company will increase the Firm Value when the company has optimized the use of assets, increasing product sales, and increasing cost efficiency. Investors believe a company with stable profits and shows an increase in a company that is worth investing in because it has prospects in the future. The form of investor participation is by purchasing company shares, thus encouraging share price increases and increasing Firm Value. An increase in profitability will increase the Firm Value because investors like companies that have shown profit-making, thus encouraging high demand for shares. Sudiani (2018), states that the higher the company's ability to earn profits, the greater the return expected by investors to make the company's value increase. These results support the signaling theory which states that profitability can affect firm value positively (Sadewo et al., 2017).

The results of this study are in line with empirical studies obtained by Sucuahi \& Jay (2016); Tauke et al. (2017); and Handayani et al. (2018), namely profitability has a positive and significant effect on firm value. Investment opportunities provide positive information that the company will show growth, thereby increasing the Firm Value.

\section{The role of profitability as mediation influence of capital structure against the firm value}

Sobel test results indicate that profitability is able to mediate the effect of capital structure on firm value in Consumer Goods companies listed on the Indonesia Stock Exchange in the 2013-2018 period. The results of this test indicate that H6 was received. Gumanti (2017), explains that if the use of debt is below the optimal point, each addition can increase the Firm Value. The use of high amounts of debt appropriately can increase profits compared to companies with high equity but are unable to manage their capital. High debt to produce high profitability is more attractive for investors to buy shares. The reason is that high debt becomes a positive signal that shows the prospects and performance of the company going forward. The high demand for shares in the capital market pushed up share prices which could reflect an increase in the Firm Value.

The results of this study are in line with an empirical study by Rahman (2012), which found that profitability was able to mediate the effect of capital structure on firm value. Data on Consumer Good's financial statements show that most companies utilize high debt in their operations. The existence of proper debt management by management is able to increase profits and encourage increased Firm Value.

\section{Conclusion}

The results of this study support the Signaling Theory, namely sales growth and profitability that have a positive effect on firm value. This means that any increase in sales growth and profitability can give a signal to investors that the company is in good condition so that investors are willing to buy shares. The high demand for shares has an impact on increasing the Firm Value. Investors always expect the benefits of their investments.

Profitability reflects the ability of management to allocate its capital effectively and efficiently in investment assets for the survival of the company. The results of the study also prove that profitability is able to act as a mediating variable in the effect of capital structure on firm value, profitability as a mediating effect of sales growth on firm value.

The negative effect of capital structure on profitability means that the use of high debt by the company will have an impact on profit decline. High corporate debt requires companies to prepare high amounts of funds to repay their debts. This condition can have an impact on decreasing company profits.

Sales growth has a positive and significant effect on profitability. This means that every increase in sales has an impact on increasing profits. These benefits come from the high income received and are able to cover the costs incurred by the company.

The results of this study also showed that sales growth had a positive and significant effect on firm value. The growth reflects if the company is feasible to be invested by investors because the company always evaluates so that each period there is an increase in performance. Conditions that can increase the company's stock price because longterm investors are interested in buying companies with positive growth. 
The results of this study found that capital structure has no effect on firm value. There are other factors that are considered more important by investors than capital structure such as Indonesian Government policies that can affect the Consumer Good sector as a whole. These factors have an impact on the Firm Value in terms of the price of shares formed on the purchase and sale of shares by investors in the capital market.

The results of this study can be used in contributing ideas to the company as a consideration in making further decisions. The first consideration is the determination of the company's strategy in forming capital structure to achieve profit targets and create corporate value in order to attract investors to invest. Second, being able to be considered in making strategies to increase product sales to achieve positive performance so that the company's survival is guaranteed. The results of this study are also expected to be used as input information by investors in determining which companies to invest by looking at the company's fundamental conditions.

\section{Conflict of interest statement}

The authors declared that they have no competing interests.

Statement of authorship

The authors have a responsibility for the conception and design of the study. The authors have approved the final article.

\section{Acknowledgments}

The authors would like to thank the editor of IRJMIS for their valuable time, support and advice in completing the current study.

Putri, I. G. A. P. T., \& Rahyuda, H. (2020). Effect of capital structure and sales growth on firm value with profitability as mediation. International Research Journal of Management, IT and Social Sciences, 7(1), 145-155. https://doi.org/10.21744/irjmis.v7n1.833 


\section{References}

Burhanuddin, Marlina Widiyanti \& Taufik. (2019). The Role of Profitability as an Intervening Variable on Analysis Impact of Debt Policy, Company Growth on Firm Value of Property and Real Estate Listed in Indonesia Stock Exchange. International Journal of Scientific Research and Engineering Development, 2 (1), pp. 312-322.

Febriyanto, F. C. (2018). The effect of leverage, sales growth and liquidity to the firm value of real estate and property sector in Indonesia stock exchange. EAJ (Economics and Accounting Journal), 1(3), 198-205. http://dx.doi.org/10.32493/eaj.v1i3.y2018.p198-205

Gumanti, T. A. (2017). Keuangan Korporat: Tinjauan Teori dan Bukti Empiris. Jakarta: Mitra Wacana Media.

Handayani, I.A. R. P., Dodik A., Rasmini N. K., \& Widanaputra, A.A. G. P. (2018). The Effect of Profitability, Institutional Ownership on The Value of the Company with Dividend Policy as a Meditation. International of Science: Basic and Applied Research (IJSBAR) Vol 41 No 1, ISSN: 2307-4531, pp. 234-242.

Handriani, E., \& Robiyanto, R. (2018). Corporate finance and firm value in the Indonesian manufacturing companies. International Research Journal of Business Studies, 11(2), 113-127. https://doi.org/10.21632/irjbs

Hoque, J., Hossain, A., \& Hossain, K. (2014). Impact Of Capital Structure Policy On Value Of The Firm-A Study On Some Selected Corporate Manufacturing Firms Under Dhaka Stock Exchange. Ecoforum Journal, 3(2), 9.

Idode, P. E., Toyin M. A., Akindele J. O., Oyekan S. A. (2014). Influence of Capital Structure on Profitability: Empirical Evidence from Listed nigerian Banks. IOSR Journal of Business and Management, 16 (11) e-ISSN: 2278-487X, pp. 22-28.

Jensen, M. C., \& Meckling, W. H. (1976). Theory of the firm: Managerial behavior, agency costs and ownership structure. Journal of financial economics, 3(4), 305-360. https://doi.org/10.1016/0304-405X(76)90026-X

Khan, M. N., \& Khokhar, I. (2015). The effect of selected financial ratios on profitability: an empirical analysis of listed firms of cement sector in Saudi Arabia. Quarterly Journal of Econometrics Research, 1(1), 1-12.

Kodongo, O., Mokoaleli-Mokoteli, T., \& Maina, L. N. (2015). Capital structure, profitability and firm value: panel evidence of listed firms in Kenya. African Finance Journal, 17(1), 1-20.

Missy, Y., Budiyanto \& Riyadi S. (2016). Influence of Capital Structure, Size and Growth on Profitability and Corporate Value. International Journal of Business and Finance Management Research, ISSN: 2053-1842, pp. 80101.

Nirajini, A., \& Priya, K. B. (2013). Impact of capital structure on financial performance of the listed trading companies in Sri Lanka. International Journal of Scientific and Research Publications, 3(5), 1-9.

Odalo, S. K., Njuguna, A. G., \& Achoki, G. (2016). Relating Sales Growth and Financial Performance in Agricultural Firms Listed In the Nairobi Securities Exchange in Kenya.

Paminto, A., Setyadi, D., \& Sinaga, J. (2016). The effect of capital structure, firm growth and dividend policy on profitability and firm value of the oil palm plantation companies in Indonesia. European Journal of Business and Management, 8(33), 123-134.

Putra, I. G. W. R., \& Sedana, I. B. P. (2019). Capital structure as a mediation variable: Profitability and liquidity on company value in real estate companies in Indonesia stock exchange. International Research Journal of Management, IT and Social Sciences, 6(4), 62-72. https://doi.org/10.21744/irjmis.v6n4.640

Rahayu, M., \& Sari, B. (2018). Faktor-Faktor yang Mempengaruhi Nilai Perusahaan. IKRA-ITH HUMANIORA: Jurnal Sosial dan Humaniora, 2(1), 69-76.

Rahman, M. A., Sarker, M. S. I., \& Uddin, M. J. (2019). The Impact of Capital Structure on the Profitability of Publicly Traded Manufacturing Firms in Bangladesh. Applied Economics and Finance, 6(2), 1-5.

Rahman, S. (2012). The role of intellectual capital in determining differences between stock market and financial performance. International Research Journal of Finance and Economics, 89(1), 46-77.

Rasyid, A. (2015). Effects of ownership structure, capital structure, profitability and company's growth towards firm value. International Journal of Business and Management Invention, 4(4), 25-31.

Sadewo, I. B., Suparlinah, I., \& Widianingsih, R. (2017). Pengaruh Ukuran Perusahaan dan Keputusan Pendanaan Terhadap Nilai Perusahaan dengan Profitabilitas sebagai Variabel Mediasi (Studi Empiris Perusahaan Manufaktur di Bursa Efek Indonesia pada Tahun 2011-2014).

Safeena, S., \& Hassan, M. G. (2014). Impact of capital structure on profitability: a study of listed manufacturing companies in the Colombo stock (sec) exchange in Sri Lanka.

Saputra, L. A. A., Surati, -, \& Saufi, A. (2019). Mediation role of job satisfaction towards effect of conflict roles on organizational commitment. International Journal of Social Sciences and Humanities, 3(2), 165-175. https://doi.org/10.29332/ijssh.v3n2.308

Sucuahi, W., \& Cambarihan, J. M. (2016). Influence of profitability to the firm value of diversified companies in the 
Philippines. Accounting and Finance Research, 5(2), 149-153. http://dx.doi.org/10.5430/afr.v5n2p149

Sudiani, N. K. A. (2018). Variabel Anteseden Nilai Perusahaan Pada Perusahaan Manufaktur di Bursa Efek Indonesai. Tesis. Fakultas Ekonomi dan Bisnis Universitas Udayana.

Tailab, M. (2014). Analyzing factors effecting profitability of non-financial US firms. Research Journal of Finance and accounting, 5(22).

Tauke, P. Y., Murni, S., \& Tulung, J. E. (2017). Pengaruh Kinerja Keuangan terhadap Nilai Perusahaan Real Estate and Property yang Terdaftar di Bursa Efek Indonesia Tahun 2012-2015. Jurnal EMBA: Jurnal Riset Ekonomi, Manajemen, Bisnis dan Akuntansi, 5(2). https://doi.org/10.35794/emba.v5i2.16009

Putri, I. G. A. P. T., \& Rahyuda, H. (2020). Effect of capital structure and sales growth on firm value with profitability as mediation. International Research Journal of Management, IT and Social Sciences, 7(1), 145-155. https://doi.org/10.21744/irjmis.v7n1.833 